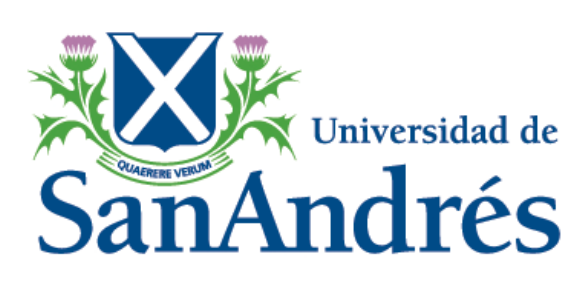
The Short-Term Effect of the Paycheck Protection Program on Unemployment Por Santiago Barraza (Universidad de San Andrés), Martín A. Rossi (Universidad de San Andrés) y
Timothy J. Yeager (University of Arkansas)

Vito Dumas 284, B1644BID, Victoria, San Fernando, Buenos Aires, Argentina Teléfono 4725-7020

Email: economia@udesa.edu.ar 


\title{
The Short-Term Effect of the Paycheck Protection Program on Unemployment*
}

\author{
Santiago Barraza \\ Universidad de San Andrés \\ Martín A. Rossi \\ Universidad de San Andrés \\ Timothy J. Yeager \\ University of Arkansas
}

This version: August 2020

\begin{abstract}
We study the short-term causal effect of the Paycheck Protection Program on unemployment. Using the 2019 density of Small Business Administration member bank offices in a county as an instrument for PPP loans originated in that county during April 2020, we find statistically and economically significant effects from the program on unemployment. Our results highlight the importance of this relief policy and the financial system infrastructure in preserving jobs during the COVID-19 crisis.
\end{abstract}

Keywords: Banks; Financial system; COVID-19; Labor Market.

JEL classification: G18.

\footnotetext{
* Santiago Barraza (sbarraza@udesa.edu.ar), Business School, Universidad de San Andrés; Martín A. Rossi (mrossi@udesa.edu.ar), Department of Economics, Universidad de San Andrés; Timothy J. Yeager (tyeager@uark.edu), Walton College of Business, University of Arkansas. Cao Fang provided excellent research assistance.
} 


\section{Introduction}

We study the short-term causal effect of the Paycheck Protection Program (PPP) on unemployment. We estimate that during the month following the launch of the program on April 3, 2020, it reduced unemployment by 1.4 percentage points.

Our main contribution is the identification of a causal effect of PPP on unemployment. Our identification strategy exploits the heterogeneity in the capacity of the banking sector in each county to process PPP loan applications as measured by the density of banking offices that were members of the Small Business Administration (SBA) in 2019. ${ }^{1}$ This county-level instrument differs in important ways over alternative instruments used in the literature. First, it permits a comprehensive estimate of the effect of PPP on U.S. unemployment using data that cover more than $98 \%$ of the labor force. In addition, the instrument is predetermined so it excludes the endogenous increase in PPP processing capacity as additional banks that were not SBA members began to process loan applications. Our results show that the unemployment path between counties with high and low SBA member office densities diverges significantly post-intervention, as expected.

The rapidly evolving literature thus far shows mixed results regarding the effects of PPP on the employment. Three studies find strong effects from the program. Bartik et al. (2020) use Homebase time-clock tracking data on small business hourly employees primarily in retail and food service. They find that small-business employees in states that received more PPP loans as a share of payroll were less likely to stop work in April 2020. The authors concede, however, that their analysis is suggestive rather than causal. Autor et al. (2020) use payroll processing data from ADP to identify causal effects from PPP through a difference-in-difference design that compares

\footnotetext{
${ }^{1}$ We estimate that two-thirds of the first round of PPP loans were made by 2019 SBA members, which includes all the largest banks.
} 
employment trends of small businesses below and above 500 employees, which is the approximate size cutoff for PPP loan eligibility. Their preferred estimate is that PPP boosted employment at eligible firms by 3.25 percent. Humphries et al. (2020) use survey evidence to show that small businesses that received PPP loans were 9 percentage points less likely to have fewer employees than in January 2020.

Two studies find modest or no effects on employment from PPP. As with Autor et al. (2020), Chetty et al. (2020) use a difference-in-difference approach around the 500-employee PPP eligibility cutoff using payroll information from Earnin. The authors conclude that the PPP had little effect on small business employment; however, they cannot rule out a positive employment effect of 3 or 4 percentage points, which they consider small relative to the large number of jobs lost in the weeks after the COVID-19 shock. Closer to our approach, Granja et al. (2020) exploit the geographical heterogeneity of banks' observed origination of PPP loans relative to their typical small business loan volume. Because the average large bank processed PPP loans slowly in the first round of the program, small business access to PPP loans was hindered in the large-bank lending markets. The authors show that counties where bank processing of PPP loan applications greatly exceeded their typical small business loan volumes had significantly lower unemployment insurance filings than other counties, consistent with a beneficial effect from PPP. However, the divergence in unemployment claims between counties with relatively high-volume versus lowvolume processors emerges in the two weeks prior to the start of PPP, which they attribute to adverse effects from the economic lockdown induced by the pandemic. The authors find no additional divergence in claims after PPP implementation. Autor et al. (2020) also find some evidence of a positive employment effect in the weeks just prior to the April 3 implementation date, but they attribute the results in part to firms' retention of workers in anticipation of PPP loans, and they do find an effect from PPP post-intervention. 
We find that, on average, the PPP improved county employment across the board. Consistent with Granja et al. (2020) and Liu and Volker (2020), our evidence also attributes small and regional banks a significant role in this result because counties with high-density offices tend to have a high proportion of these banks that were particularly efficient at processing loan applications in the initial weeks of the program.

Our paper proceeds as follows. Section II provides background on the PPP and discusses the identification strategy. Section III describes the data. Section IV presents the econometric methods and reports the results. Section V concludes.

\section{Paycheck Protection Program}

The Paycheck Protection Program was created as part of the Coronavirus Aid, Relief, and Economic Security (CARES) Act, which was signed into law on March 27, 2020. The program objective is to provide financial support to small businesses to keep their businesses afloat and workers employed. Through delegated authority from the SBA, banks lend 100\% governmentguaranteed funds to businesses to cover eight weeks of eligible payroll, rent, and utility expenses. ${ }^{2}$ Although the interest rate is $1 \%$, the loan is forgiven in full or in part after lenders verify that the funds have been used for eligible expenses. Payments for ineligible expenses can be deferred at least six months following loan disbursement.

Businesses eligible for a loan include small business concerns with primary residence in the U.S. that were in operation on or before February 15, 2020 and have 500 or fewer employees (or otherwise meet employee-based industry size standards). Lenders already certified as SBA 7(a) lenders prior to passage of the CARES Act are automatically eligible to participate as lenders in the PPP program. ${ }^{3}$ Most other federally insured depository institutions (and non-bank institutions)

2 "Business Loan Program Temporary Changes; Paycheck Protection Program," SBA Interim Final Rule, April 5, 2020.

${ }^{3}$ The 7(a) loan program is the main program through which SBA provides financing to small businesses. 
are automatically eligible to participate upon submission of the Lender Agreement (SBA Form 3506).

The first phase of PPP set aside $\$ 349$ billion in government-guaranteed forgivable loans. The SBA began processing new lender applications on April 3, 2020. Demand was strong, and funding was depleted as of April 16. Congress replenished the fund with an additional $\$ 310$ billion in funding, signed into law April 24, and the SBA resumed processing small business loan applications on April 27.

\section{Data}

\section{$\underline{\text { Unemployment data }}$}

We collect monthly county-level labor data through April 2020 from the Local Area Unemployment Statistics (LAUS) program, Bureau of Labor Statistics. ${ }^{4}$ For each county-month, we compute the unemployment rate as the ratio of unemployed to total civilian labor force. During the early stages of the COVID-19 crisis in April 2020, the average unemployment rate in U.S. counties rose by 7.64 percentage points, from $4.81 \%$ at the end of March to $12.45 \%$ at the end of April. We also use changes in weekly unemployment initial claim rates (UICR), generously made available by Chetty et al. (2020). ${ }^{5}$

\section{$\underline{\text { Banking data }}$}

The FDIC Summary of Deposit database contains the geographic location and deposits of every (thrift and commercial) bank office, which includes the headquarters office and branches as of June 30 each year. ${ }^{6}$ We retrieve the 2019 data and retain full service, retail, and loan production offices, and we aggregate by bank the number of offices and deposits at the county level.

\footnotetext{
${ }^{4}$ https://www.bls.gov.

${ }^{5}$ https://github.com/Opportunitylab/EconomicTracker/tree/main/data.

${ }^{6}$ https://www7.fdic.gov/sod/dynaDownload.asp?barItem=6.
} 
We also identify banks that were "SBA members" in $2019 .{ }^{7}$ We do so by extracting from the SBA 7(a) loan database distinct banks that made at least one loan in 2019 through the 7(a) program. ${ }^{8}$ Unlike the PPP data, this database includes the bank headquarters zip code, city, county, and state. We match banks in the SBA 7(a) database to the FDIC list of banks in 2019 to obtain the unique FDIC certificate (cert) number via a two-step process. We first match by a ninecharacter string of bank name, state, and zip code. We then match the remaining banks by the same nine-character name and state, excluding zip code. Because this process is less precise than matching by zip code, we manually identify incorrect matches based on full name discrepancies and remove them from the database. In the end, we identify 1,383 SBA member banks that participated in the SBA 7(a) lending program in 2019. They spread across 2,778 counties and 50 states plus DC, encompassing 98.9 percent of the population and 98.4 of the labor force in the U.S.

We then merge by FDIC cert number the SBA-member database with the county-bank aggregated summary of deposits database. Finally, we aggregate the county-bank database to the county level and merge in county-level population data for 2019 from the U.S. Census Bureau. The resulting database allows us to compute the per-capita number of offices, banks, and deposits at the county level for all banks and for SBA member banks.

\section{$\underline{\text { PPP data }}$}

Because our analysis is at the county level, we aggregate the PPP loan data by the county of the borrower. We retrieve the PPP data for the period April 3-June 30, 2020 from the SBA website. ${ }^{9}$ The borrower's county is not in the database so we map zip code to county using the HUD-USPS Zip Crosswalk Zip-County file. ${ }^{10}$ Roughly, one-third of zip codes match to multiple

\footnotetext{
${ }^{7}$ Of course, all PPP lenders are also SBA members eligible to participate in that program, but we use this terminology for clarity to identify SBA 7(a) members prior to the PPP.

${ }^{8}$ https://www.sba.gov/about-sba/open-government/foia.

${ }^{9} \mathrm{https}$ //www.sba.gov/funding-programs/loans/coronavirus-relief-options/paycheck-protection-program.

${ }^{10}$ Obtained at https://www.huduser.gov/portal/datasets/usps_crosswalk.html.
} 
counties, so we split the PPP loan count across the counties by the percentage of businesses in the zip code located in each county using the Business Ratio weight provided in the crosswalk.

\section{Other data}

Our estimation equations include four control variables. In addition to county-level deposits, we include the county COVID case rate as of March 31, 2020 provided by Chetty et al. (2020) and downloaded from Economic Tracker. ${ }^{11}$ The share of small businesses in a county with 500 or fewer employees is computed from the 2017 County Business Patterns data. ${ }^{12}$ Finally, county population density is computed as 2019 population divided by square miles of land area in 2010 using data from the 2019 Census Bureau.

Table 1 reports summary statistics of the data.

\section{Econometric methods and results}

Our objective is to estimate the causal effect of PPP loans on unemployment. Formally, we wish to estimate the following equation:

$$
\Delta \text { Unemployment }_{c s}=\beta+\alpha \text { PPP } \text { Loans }_{c s}+\gamma X_{c s}+\delta_{s}+\varepsilon_{c s}
$$

where $c$ indexes counties, $s$ indexes states, $X_{c s}$ is a vector of county-level controls, $\delta_{s}$ is a state fixed effect, and $\varepsilon_{c s}$ is an error term. The coefficient of interest is $\alpha$.

PPP Loans is potentially endogenous in equation (1). A self-evident reason is that firms in counties with more acute unemployment problems could be more likely to apply for PPP loans, thus reversing the order of causality. Hence, we estimate equation (1) by 2SLS, where the variable SBA Member Offices is an instrument for PPP Loans. The choice of our instrument is motivated by the frictions introduced by the sheer magnitude of originating the millions of PPP loans in a

\footnotetext{
${ }^{11} \mathrm{https} / / /$ tracktherecovery.org.

122017 County Business Patterns and 2017 Economic Census, "Number of Firms, Number of Establishments, Employment, and Annual Payroll by Enterprise Employment Size for Counties, Totals: 2017," downloaded 31 June 2020 at https://www.census.gov/data/tables/2017/econ/susb/2017-susb-annual.html.
} 
short timeframe. ${ }^{13}$ Thus, our identification strategy exploits the heterogeneity across counties in the agility of the banking industry to process the loan applications. The most apparent reason why counties with a high-density banking sector would have an advantage in processing loan applications quickly is that more employees are available to do the time-intensive work -45 minutes per loan application according to one loan officer at a large bank - of inputting borrower information into E-Tran, the SBA's electronic system for loan processing. ${ }^{14}$ Moreover, banks in counties with high per-capita densities of SBA member offices may have also had an advantage in loan processing over counties with lower SBA member office densities because banks involved in the SBA 7(a) lending program already had relevant administrative experience and compliance information required by the SBA on their small business clients.

More formally, to be a suitable instrument for PPP Loans, the variable SBA Member Offices needs to be both relevant and exogenous. We first explore the exclusion restriction, or the exogeneity of SBA Member Offices in equation (1). Our key identifying assumption is that SBA member office density affects unemployment only through PPP loans. A natural concern is that banks can affect unemployment via other functions they perform, such as holding deposits or extending credit lines that provide liquidity on demand. Because the application process for PPP loans began April 3, we test the identification assumption by examining the correlation between the density of SBA member offices and pre-treatment changes in unemployment. We compute the change in unemployment at the county level for each of the four months prior to the launch of the program (December 2019 to March 2020). As shown in Table 2, the density of SBA member offices in a county is uncorrelated with changes in unemployment for all the pre-treatment periods,

\footnotetext{
${ }^{13}$ Lenders originated, and the SBA approved, roughly 2.9 million business loans during April 2020. A ballpark estimate based on the outstanding 24 million small business loans on bank balance sheets on the Call Reports and a 56-month average loan maturity obtained from the Federal Reserve Bank of Kansas City Small Business Lending Survey (fixed-rate, term loans), suggests this volume is about 6.8 times the number of small business loans banks process during a typical month.

${ }^{14}$ WSJ, 7 April 2020, "Lawmakers, White House Vow to Quickly Provide More Small-Business Loans."
} 
even during March 2020 when Li et al. (2020) find evidence of significant drawdowns at certain banks, validating our identification assumption.

Although the density of SBA member offices is orthogonal to pre-treatment changes in unemployment, a potential concern is that the orthogonality measured at a monthly frequency in normal times no longer holds in the early days or weeks of a labor market crisis such as the COVID-19 pandemic just prior to the policy intervention. To address this concern, and to further validate our identification assumption, we examine changes in weekly unemployment initial claim rates (UICR) beginning January 11, 2020. These data cover a subset of 1,424 counties. Figure 1 presents average weekly UICR for counties in the fourth quartile of SBA member office density and the rest of the quartiles. According to the figure, the evolution of UICR before PPP was launched is similar across counties with different SBA member office density - even when claims suffered their sharpest jump the week ending Saturday March 28. The paths of UICR diverge only after PPP is launched as seen in the figure for the week ending Saturday, April 4. Thus, this evidence eases concern that other banking functions could have affected unemployment differently across counties with different SBA member office densities in the wake of the onset of the COVID19 pandemic and prior to the policy intervention.

We now explore the relevance of our instrument by examining the link between $S B A$ Member Offices and PPP Loans. ${ }^{15}$ Columns (1) and (2) in Table 3 report first-stage estimates, without and with controls. In all cases, first-stage effects are precisely estimated and indicate that those counties with more SBA member offices are more likely to originate PPP loans compared to counties with fewer SBA member offices.

\footnotetext{
${ }^{15}$ Figure A1 in the Online Appendix displays the average number of PPP loans originated in April 2020 by counties in the top quartile of SBA member office density and the remaining counties. Banks in counties in the top office density quartile originated, on average, nearly twice as many loans as the other counties, consistent with the intuition that our instrument identifies the most agile banking offices across counties. Figure A2, also in the Online Appendix, presents heat maps of SBA member office density (Panel A) and PPP loans (Panel B) that reinforce the intuition.
} 
Figure 2 provides a preview of our main results. The figure displays the evolution of countylevel unemployment between November 2019 and April 2020 according to county-level density quartiles of SBA member offices in 2019. Consistent with results displayed in Table 2 and Figure 1, the figure shows that both the level and trend of unemployment are unrelated to the density of SBA member offices in all the pre-intervention period (November 2019-March 2020). In contrast, the divergence begins only in April when the PPP was launched. In the post-intervention period, counties with high SBA member office densities experience far lower increases in unemployment rates than counties with lower densities.

Columns (3) and (4) in Table 3 report reduced-form estimates of the link between SBA Member Offices and $\triangle$ Unemployment, without and with controls. The coefficient on SBA Member Offices is always negative and statistically significant, indicating that those counties with higher SBA member office densities are more likely to have smaller increases in unemployment during the COVID-19 crisis than those counties with lower SBA member office densities.

Columns (5) and (6) in Table 3 report our main results, the 2SLS estimates of equation (1). The coefficient of PPP Loans is negative and significant. The magnitude of the coefficient is meaningful: an increase of one standard deviation in PPP loans per 10,000 people is associated with approximately a 0.25 standard deviation decrease in the change in unemployment at the early stages of the COVID-19 crisis. $^{16}$ The average-sized county in our sample (with approximately 104,000 people) received 1,180 loans, which saved $1.4 \%$ of the 48,880 labor force in that county, or 684 jobs. $^{17}$

We also conducted additional analysis to explore the beneficial role that small and regional

\footnotetext{
${ }^{16}$ All results are robust to using the change in unemployment between December 2019 and April 2020. All findings mentioned but not shown are available from the authors upon request.

${ }^{17}$ County-level BLS data show a mean labor force participation rate of $47 \%$ of the population as of December 2019.
} 
banks played in distributing PPP funding. Importantly, all our results hold if we define the measure of SBA member office density as the number of bank offices with assets less than $\$ 100$ billion at year-end 2019, an asset threshold that excludes the 29 largest banks in the U.S. ${ }^{18}$ In fact, the economic significance of the effect of PPP on unemployment is larger than when including all SBA member offices. This result is expected because the share of small and regional offices in the quartile of counties with the highest office density is $82 \%$ compared with a $60 \%$ share in the quartile of counties with the lowest office density.

\section{Final remarks}

We present causal evidence on the palliative effect of the Paycheck Protection Program on unemployment during its first month of implementation. To our knowledge, this is the first causal work that estimates the impact of PPP on nearly the entire labor force in the United States, which should make a valuable contribution to the evolving analysis of the economic effects of this historic relief program.

The issue of efficacy of PPP embeds two fundamental questions. First, was the program allocated where it was most necessary? Second, where allocated, did the program achieve its desired goals? Although our paper directly addresses the latter question, in so doing, it also hints at some subtle relations with allocation. Our findings suggest that the pre-existing banking infrastructure was a significant determinant of loan allocation. To the extent that we can assume that this infrastructure was less than perfectly related with the pandemic shock, we can also assume that loans have not necessarily been allocated where they were needed the most. Thus, studies whose designs are meant to assess the efficacy of the program in terms of allocation efficiency

${ }^{18}$ See Table A1 in the Online Appendix. 
only or combine both questions at once, are likely to find slightly different results. Those results should be deemed complementary to ours, rather than substitute or contradictory. 


\section{References}

Autor, David, David Cho, Leland D. Crane, Mita Goldar, Byron Lutz, Joshua Montes,

William B. Peterman, David Ratner, Daniel Villar, and Ahu Yildirmaz (2020). “An Evaluation of the Paycheck Protection Program Using Administrative Payroll Micro-data." Working Paper, MIT July 2020.

Bartik, Alexander, Marianne Bertrand, Feng Lin, Jesse Rothstein, and Matthew Unrath (2020). "Measuring the Labor Market at the Onset of the COVID-19 Crisis." University of Chicago, Becker Friedman Institute for Economics Working Paper No. 2020-83.

Chetty, Raj, John N. Friedman, Nathaniel Hendren, and Michael Stepner (2020). “The Opportunity Insights Team. How Did Covid-19 And Stabilization Policies Affect Spending And Employment? A New Real-Time Economic Tracker Based On Private Sector Data.” NBER Working Paper No 27431.

Granja, João, Christos Makridis, Constantine Yannelis, and Eric Zwick (2020). "Did the Paycheck Protection Program Hit the Target?” NBER Working Paper No. 27095.

Humphries, John, Christopher Nelson, and Gabrile Ulyssea (2020). "Information Frictions and Access to the Paycheck Protection Program.” IRS Working Papers no. 643.

Li, Lei, Philip E. Strahan, and Song Zhang (2020). "Banks as Lenders of First Resort: Evidence from the COVID-19 Crisis.” NBER Working Paper No. 27256.

Liu, Haoyang and Desi Volker (2020). "Where Have the Paycheck Protection Loans Gone So Far?” Liberty Street Economics, Federal Reserve Bank of New York. 
Table 1. Summary statistics

\begin{tabular}{lrrrr}
\hline & Mean & $\begin{array}{c}\text { Standard } \\
\text { Deviation }\end{array}$ & Minimum & Maximum \\
\hline UUnemployment & 7.64 & 4.92 & -4.38 & 32.43 \\
SBA Member Offices & 2.28 & 1.72 & 0.14 & 21.01 \\
PPP Loans & 117.88 & 82.48 & 0.00 & 774.25 \\
Deposits (\$000s) & 23.22 & 65.43 & 0.93 & $3,454.59$ \\
Population Density & 269.31 & $1,781.35$ & 0.04 & $71,340.39$ \\
COVID exposure & 19.10 & 56.76 & 0.00 & $1,030.00$ \\
Small Business Share & 0.90 & 0.04 & 0.51 & 1.00 \\
& & & &
\end{tabular}

Notes: $\Delta$ Unemployment is the change in the monthly county-level unemployment rate in April 2020. SBA Member Offices is the county-level number of offices of SBA-affiliated banks in 2019, per 10,000 people. PPP Loans is the number of loans originated in April 2020 to firms located in a given county, per 10,000 people. Deposits is the county-level, per capita dollar amount of deposits in June 2019, in thousands of U.S. dollars. Population Density is the population density of the county, as in 2019. COVID exposure is the county COVID case rate as of March 31, 2020. Small Business Share is the share of firms with 500 or fewer employees in the county. 
Table 2. SBA member offices and pre-treatment changes in unemployment

\begin{tabular}{|c|c|c|c|c|}
\hline & \multicolumn{4}{|c|}{ Dependent variable: $\Delta$ Unemployment } \\
\hline & $\begin{array}{c}\text { March } 2020 \\
\text { (1) }\end{array}$ & 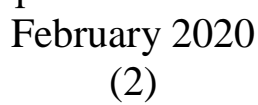 & $\begin{array}{c}\text { January } 2020 \\
\text { (3) }\end{array}$ & $\begin{array}{c}\text { December } 2019 \\
(4)\end{array}$ \\
\hline SBA Member Offices & $\begin{array}{l}-0.012 \\
(0.012)\end{array}$ & $\begin{array}{c}0.002 \\
(0.008)\end{array}$ & $\begin{array}{c}0.002 \\
(0.011)\end{array}$ & $\begin{array}{c}0.011 \\
(0.009)\end{array}$ \\
\hline State dummies & Yes & Yes & Yes & Yes \\
\hline Controls & Yes & Yes & Yes & Yes \\
\hline Number of observations & 2,777 & 2,777 & 2,777 & 2,777 \\
\hline
\end{tabular}

Notes: Standard errors clustered at the state level are shown in parentheses. All models use countylevel data in the U.S. and are estimated using Ordinary Least Squares. County-level control variables are Deposits, Population Density, COVID exposure, and Small Business Share. *Significant at the $10 \%$ level. **Significant at the 5\% level. ***Significant at the $1 \%$ level. 
Table 3. Main results

\begin{tabular}{lcccccc}
\hline \multicolumn{2}{c}{ First-stage } & \multicolumn{2}{c}{ Reduced-form } & \multicolumn{2}{c}{ 2SLS } \\
& $(1)$ & $(2)$ & $(3)$ & $(4)$ & $(5)$ & $(6)$ \\
\hline \multirow{2}{*}{ SBA Member } & $13.670^{* * *}$ & $13.761 * * *$ & $-0.198 * * *$ & $-0.195 * * *$ & & \\
Offices & $(2.195)$ & $(2.044)$ & $(0.063)$ & $(0.060)$ & & \\
PPP Loans & & & & & $-0.014 * *$ & $-0.014 * * *$ \\
& & & & $(0.006)$ & $(0.005)$ \\
F-statistic [CV] & $38.78[16.38]$ & $45.34[16.38]$ & & & & \\
State dummies & Yes & Yes & Yes & Yes & Yes & Yes \\
Controls & No & Yes & No & Yes & No & Yes \\
Observations & 2,778 & 2,777 & 2,778 & 2,777 & 2,778 & 2,777 \\
Estimation method & OLS & OLS & OLS & OLS & $2 S L S$ & $2 S L S$ \\
& & & & & &
\end{tabular}

Notes: Standard errors clustered at the state level are shown in parentheses. All models use countylevel data in the U.S. In models (1) and (2) the instrumented variable is PPP Loans. In models (3) to (6) the dependent variable is $\Delta$ Unemployment. F-statistic is the Kleibergen-Paap Wald rk F statistic, which is compared to Stock-Yogo weak ID test critical values (10\% level). County-level control variables are Deposits, Population Density, COVID exposure, and Small Business Share. In 2SLS models, PPP Loans is instrumented using SBA Member Offices. *Significant at the $10 \%$ level. **Significant at the $5 \%$ level. ***Significant at the $1 \%$ level. 
Figure 1. Evolution of weekly unemployment claims by density of SBA member offices

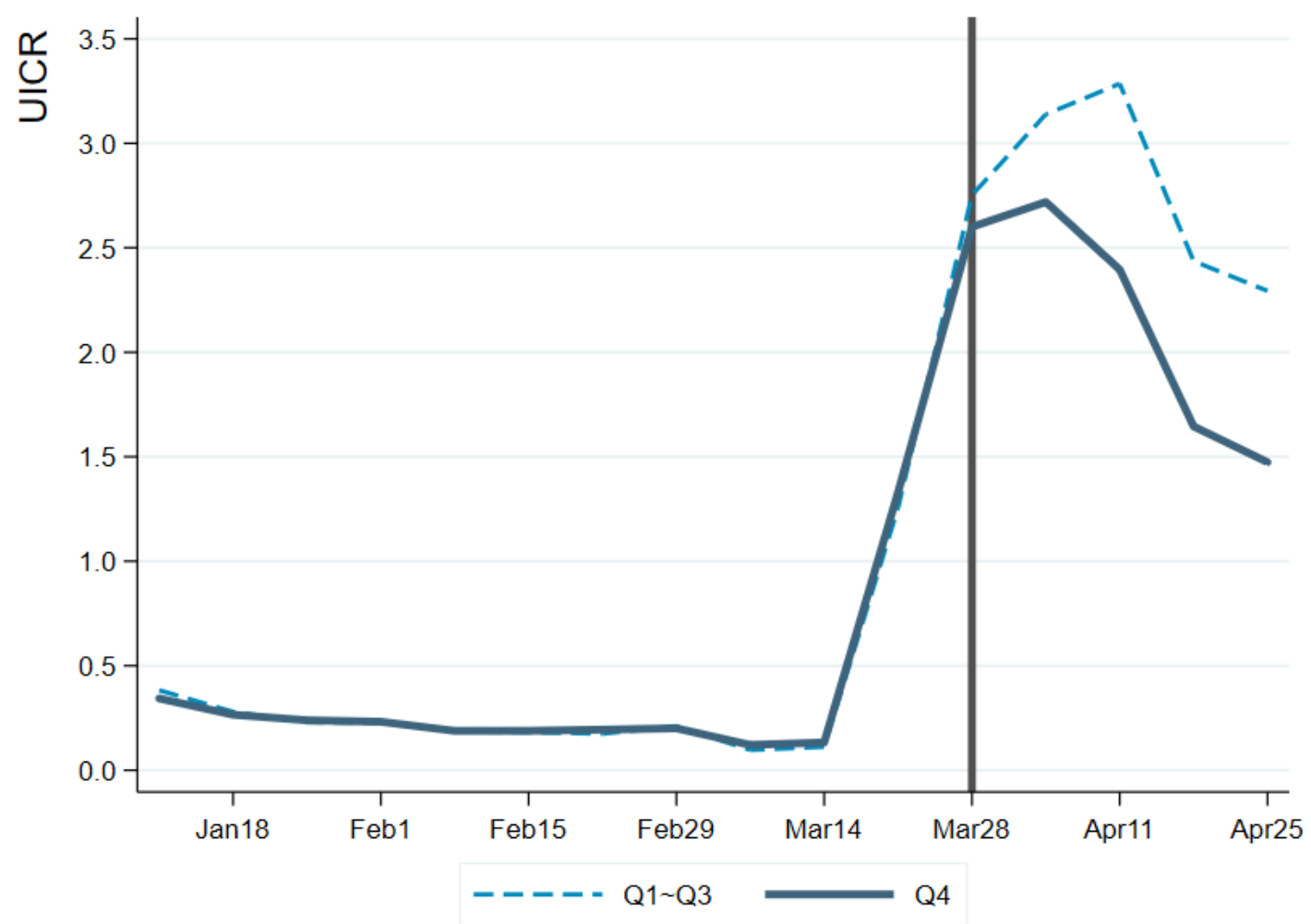

Notes: Weekly unemployment claims at county level, January-April 2020. Qs indicate quartiles of the county-level density of SBA member offices. 
Figure 2. Evolution of monthly unemployment rate by density of SBA member offices

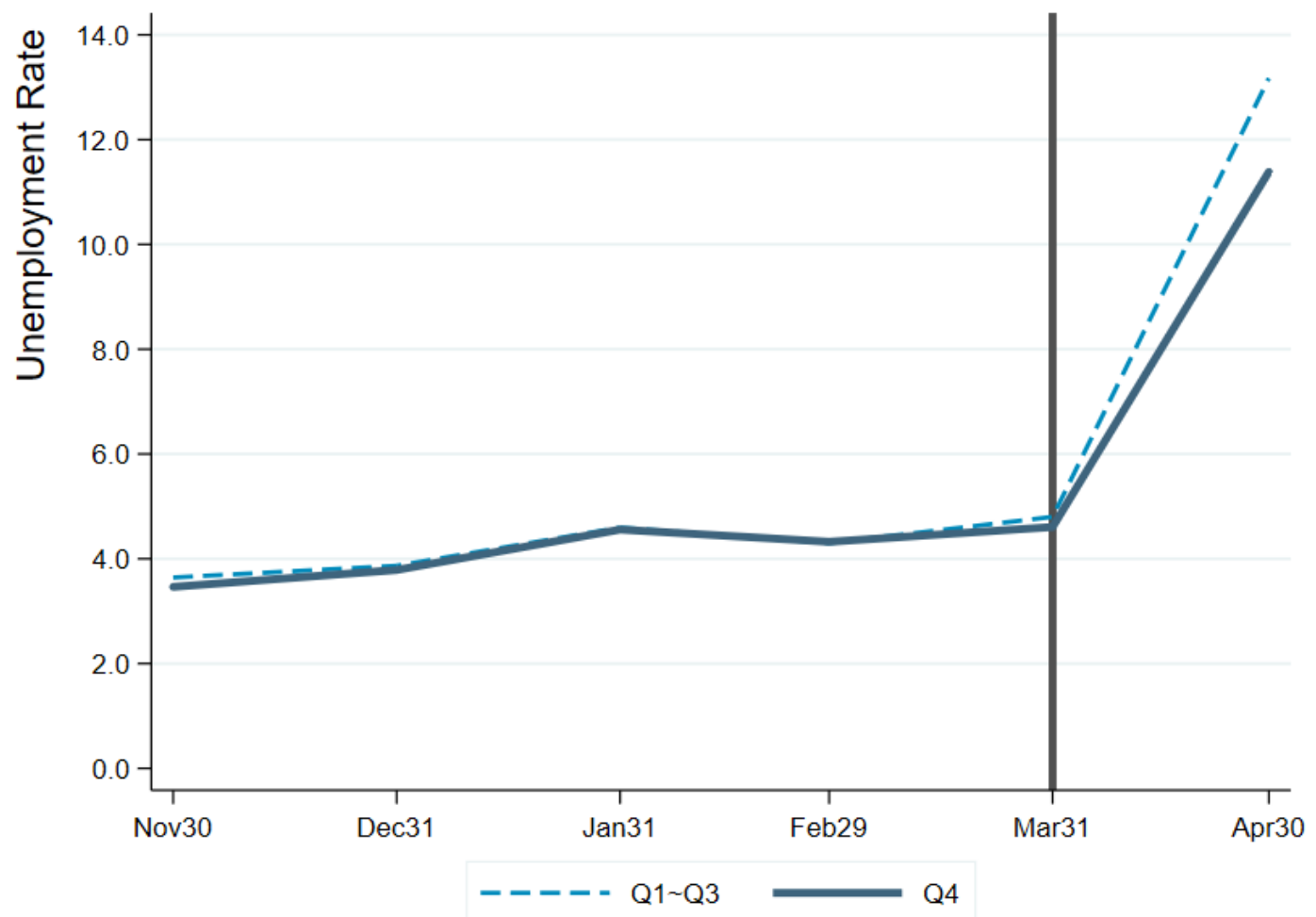

Notes: Monthly county unemployment rate, November 2019-April 2020. Qs indicate quartiles of county-level density of SBA member offices. 


\section{Online Appendix}

Table A1. Results using only small and regional banks

\begin{tabular}{|c|c|c|c|c|c|c|}
\hline & \multicolumn{2}{|c|}{ First-stage } & \multicolumn{2}{|c|}{ Reduced-form } & \multicolumn{2}{|c|}{ 2SLS } \\
\hline & (1) & (2) & (3) & (4) & (5) & (6) \\
\hline SBA Member & $13.307 * * *$ & $13.514 * * *$ & $-0.318 * * *$ & $-0.304 * * *$ & & \\
\hline Offices & $(2.055)$ & $(1.870)$ & $(0.046)$ & $(0.044)$ & & \\
\hline PPP Loans & & & & & $\begin{array}{c}-0.024 * * * \\
(0.005)\end{array}$ & $\begin{array}{c}-0.022 * * * \\
(0.004)\end{array}$ \\
\hline F-statistic [CV] & $41.93[16.38]$ & $52.25[16.38]$ & & & & \\
\hline State dummies & Yes & Yes & Yes & Yes & Yes & Yes \\
\hline Controls & No & Yes & No & Yes & No & Yes \\
\hline Observations & 2,703 & 2,702 & 2,703 & 2,702 & 2,703 & 2,702 \\
\hline Estimation method & OLS & OLS & OLS & OLS & 2SLS & 2SLS \\
\hline \multicolumn{7}{|c|}{$\begin{array}{l}\text { Notes: Standard errors clustered at the state level are shown in parentheses. All models use county- } \\
\text { level data in the U.S. In models (1) and (2) the instrumented variable is PPP Loans. In models ( } 3 \text { ) } \\
\text { to (6) the dependent variable is } \triangle \text { Unemployment. F-statistic is the Kleibergen-Paap Wald rk F } \\
\text { statistic, which is compared to Stock-Yogo weak ID test critical values ( } 10 \% \text { level). County-level } \\
\text { control variables are Deposits, Population Density, COVID exposure, and Small Business Share. } \\
\text { In 2SLS models, PPP Loans is instrumented using SBA Member Offices. *Significant at the } 10 \% \\
\text { level. **Significant at the } 5 \% \text { level. ***Significant at the } 1 \% \text { level. }\end{array}$} \\
\hline
\end{tabular}


Figure A1. Average number of county PPP loans by density of SBA member offices

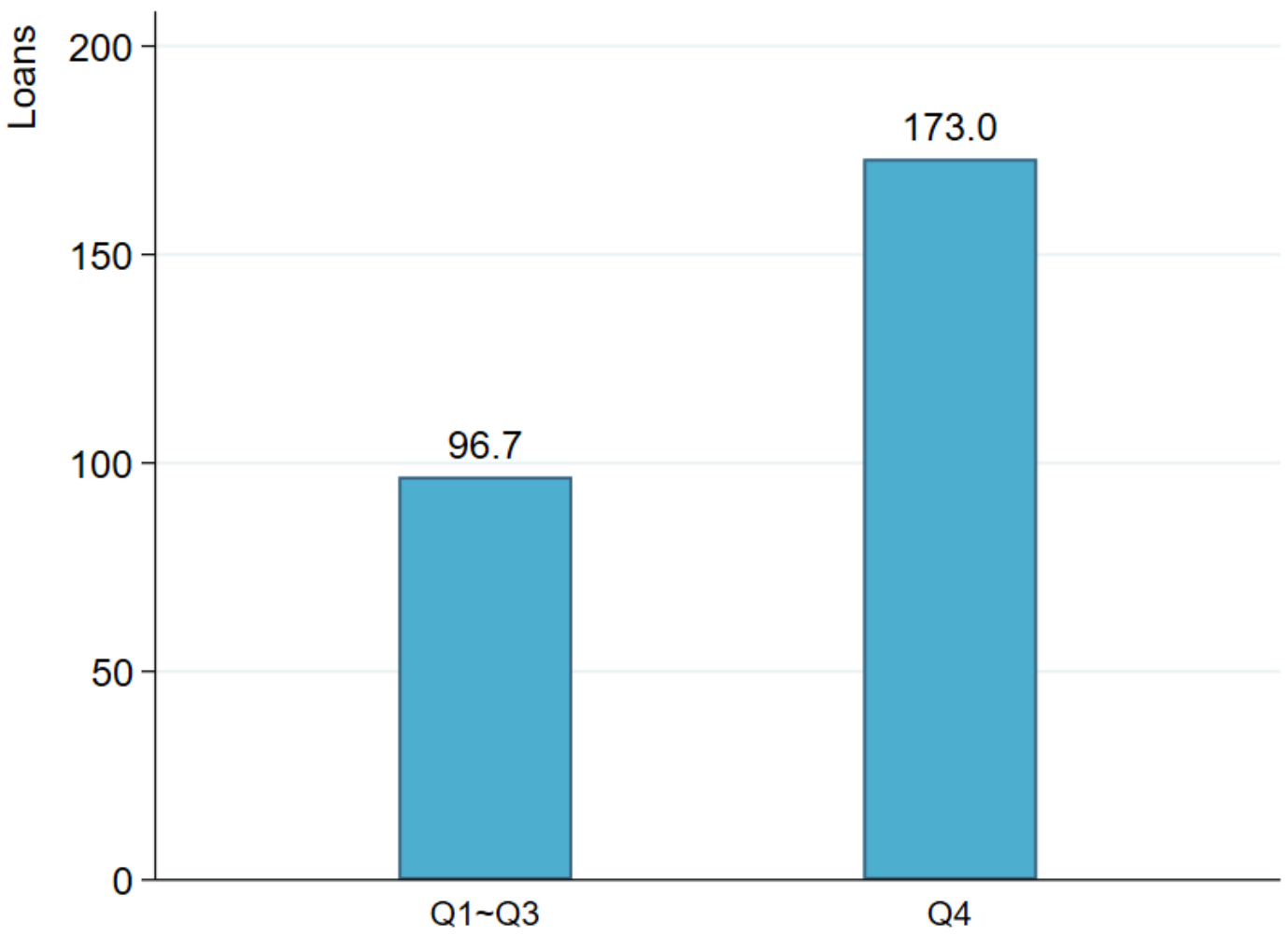

Notes: Average number of PPP loans approved in April 2020 by counties in the first three quartiles (Q1-Q3) and top quartile $(\mathrm{Q} 4)$ of the distribution of the density of county-level SBA member offices. 


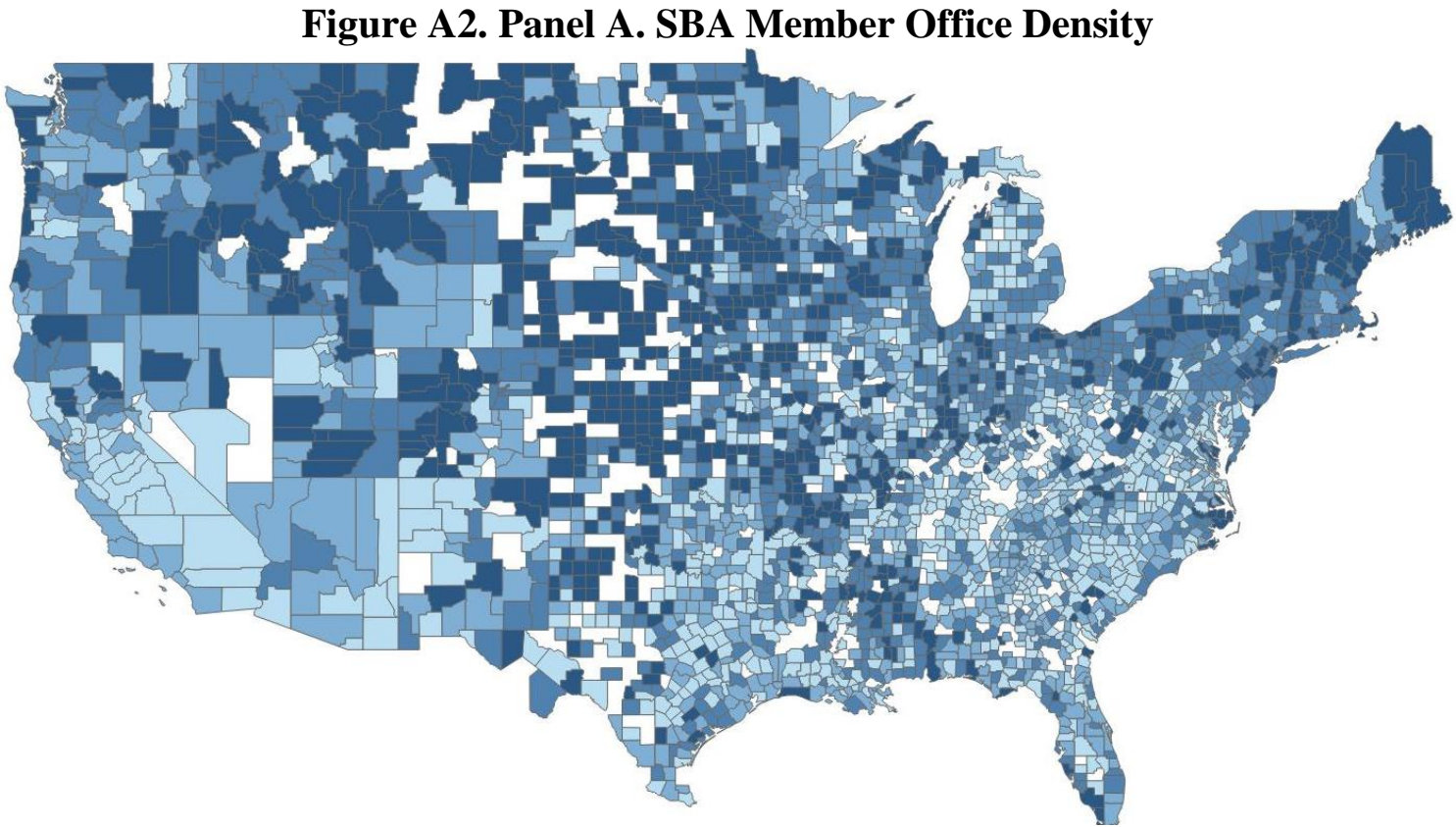

Notes: Heat map of SBA member office density. Darker shades represent counties with higher office density in 2019. Map courtesy of Tableau software. We are grateful for their generosity.

Figure A2. Panel B. PPP Loans

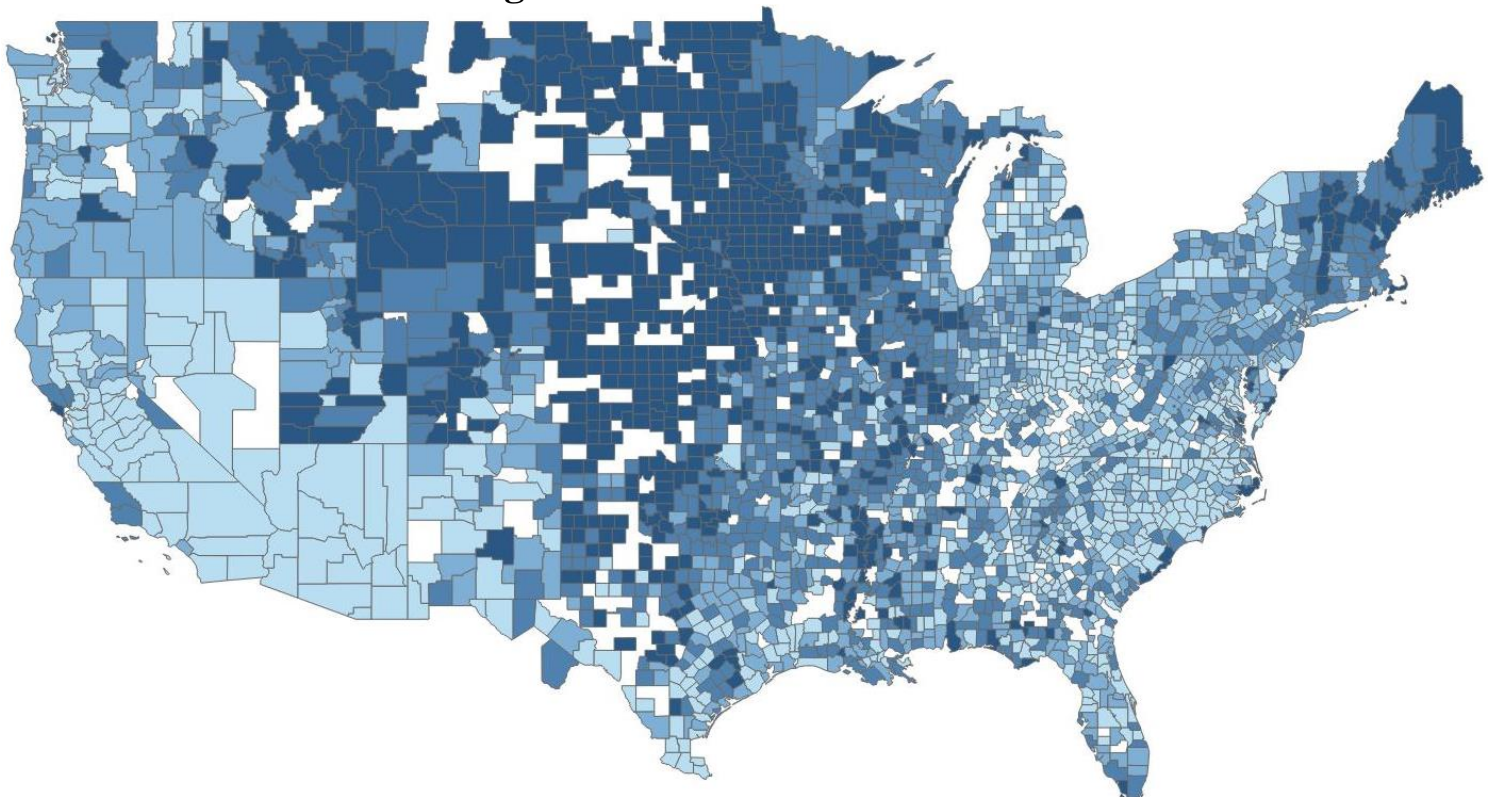

Notes: Heat map of PPP Loans. Darker shades represent counties with more PPP loans in April 2020. Map courtesy of Tableau software. We are grateful for their generosity. 